\title{
横穴を設けた配管の流動特性 Flow characteristics of pipe with side holes
}

\author{
○学 河野功典（九工大院） 正 田中和博（九エ大） 正 渕脇正樹（九エ大）
}

Kosuke KAWANO , Kyushu Institute of Technology , Kawazu 680-4 , lizuka , Fukuoka 820-0053 Kazuhiro TANAKA, Kyushu Institute of Technology, Kawazu 680-4, lizuka, Fukuoka 820-0053 Masaki FUCHIWAKI , Kyushu Institute of Technology , Kawazu 680-4 , lizuka , Fukuoka 820-0053

The discharge flow into the atmosphere is used for industrial use such as a sprinkler and a thaw system of track. For high efficiency and high precision of these systems, it is necessary to spray the same flow rate for dispersion domain. However, characteristics of discharge from side holes of a pipe have not been clarified. The purpose of the present study is to perform numerical analysis of pipe-inside flow including gas-liquid two-phase discharge flow from the side holes of the pipe and is to clarify a key factor of pipe flow with side holes.

Key Words: Numerical analysis , Flow characteristics , Gas-liquid two-phase flow

\section{1. 緒言}

配管に横穴を設け，管内流体を大気中に放出する流れ場は， 農業や建物に用いられる散水スプリンクラーや線路の消雪 システムなどに用いられている。これらの装置の運転コスト の削減や高精度化を図るためには, 散布領域に対し水の流量 を均一に散布することが望ましく，そのためには，配管内お よび流出後の流動特性について明らかにする必要がある。こ れまでに横穴を設けた配管についての研究報告はなされて いるが(1)(2)，配管外部の流動特性について報告されたものは 少ない.さらには, 配管から大気中に放出する流れ場である ため, 空気と水の二相流という複雑な流れ場であること，ま た，一般的な配管と異なり横穴を設けているため，横穴のな い通常配管を対象とした流体工学の関係式が適用できない 点で, 興味深い研究対象である.

そこで本研究の目的を，横穴を複数設けた配管の流出特性 を, 気液二相流の数值解析により明らかにしていくこととす る. 具体的には，横穴を 2 個設けた配管の管内圧力，流出寸 る水の流量および平均流出速度について調べ, 流出流量を決 定するパラメータを明らかにした。

\section{2. 解析対象および解析条件}

\section{2-1 解析対象}

本研究の解析対象を図 1 に示す.全長および主管長が $L=2$ [m]および管径 $D=20[\mathrm{~mm}]$ の配管に， $x$ 方向に横穴を 2 個設 けている。横穴の間隔は $300[\mathrm{~mm}]$ である。横穴の形状は円形 であり，横穴径は $d=10[\mathrm{~mm}]$ で，主管から $l=5[\mathrm{~mm}]$ 突き 出寸形状となっている.

\section{2-2 支配方程式}

本研究の数值解析で用いた支配方程式は，式(1)および式 (2)に示すように, 連続の式および非圧縮性流体におけるナビ エ・ストークス方程式である. 気液二相流の数值解析におい ては，VOF モデルを使用し，式(3)は VOF モデルに用いられ る体積分率方程式である。相間の界面追跡は連続の式，ナビ エ・ストークス方程式および体積分率方程式を有限体積法に より離散化し計算を行った。

$$
\begin{aligned}
& \frac{\partial \rho}{\partial t}+\nabla \cdot(\rho \vec{v})=0 \\
& \frac{\partial \rho}{\partial t}(\rho \vec{v})+\nabla \cdot(\rho \vec{v} \vec{v})=-\nabla p+\nabla^{2}(\mu v)+\vec{F} \\
& \frac{\partial f}{\partial t}+\vec{v} \cdot \nabla f=0
\end{aligned}
$$

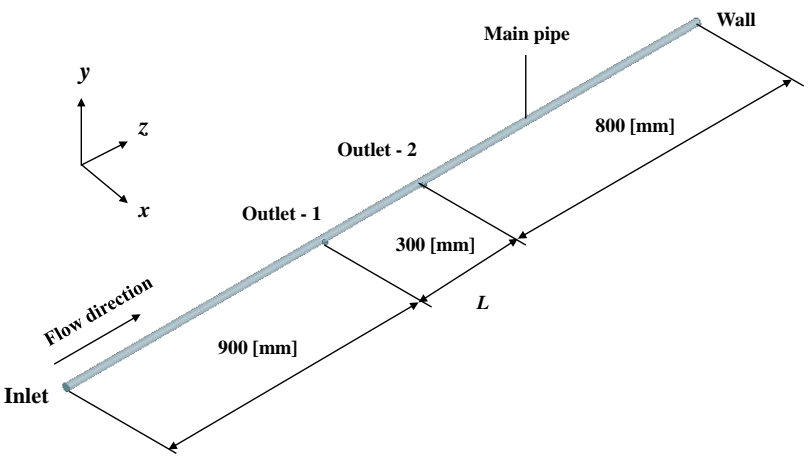

(a) 3D View

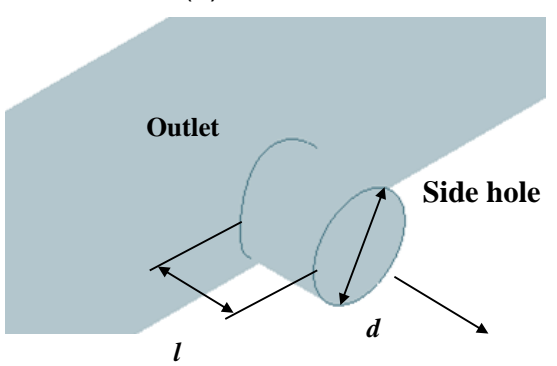

(b) Detail of side hole

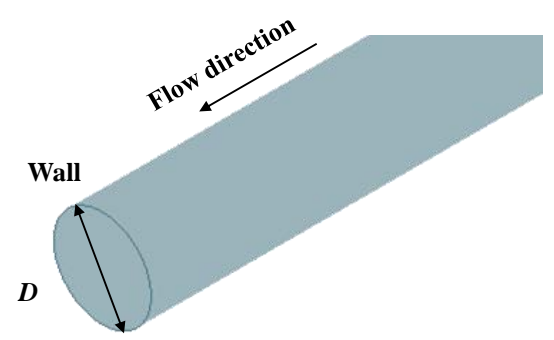

(c) Detail of main pipe

Fig.1 Analysis model

\section{2-3 解析条件}

数值解析は 3 次元定常解析を行う.配管内を解析領域とし, 流出境界の横穴出口ではゲージ圧 $0[\mathrm{~Pa}]$ を与える。また，壁 面境界は摩擦を考慮した壁面とする。流入境界は水の入口流 速を $0.5[\mathrm{~m} / \mathrm{s}], 1.5[\mathrm{~m} / \mathrm{s}], 2.5[\mathrm{~m} / \mathrm{s}]$ とし，入口流速の違いによ る流出特性の変化を調べた。計算格子数は約 600,000 格子と し, 乱流モデルは $k-\varepsilon$ モデルで数值解析を行った. 


\section{3. 解析結果および考察}

図 2 に入口流速 $V_{i n}=1.5[\mathrm{~m} / \mathrm{s}]$ における横穴を 2 個設けた配 管の主管軸方向での管内圧力を示す。縦軸および横軸は, ゲージ圧および入口からの距離である.また，(1)（5)の番号 は, $x y$ 平面における配管内の位置を示し, 各位置における管 内圧力の結果を示寸. (2)の横穴近傍での圧力のみは急激に低 下し，その直後に増加していることがわかる．これは，横穴 が大気に面しており，それに伴い管内圧力も低下寸るため， 水が主管と横穴に分岐する際に，水が壁面に衝突し，静圧が 瞬間的に増加するためであると考えられる．また，管全体で は，通常の配管とは異なり，周方向 (3)〜(5))のいずれの位置 においても管内圧力は階段状に増加することがわかる。これ も, 横穴での流れの分岐の際に圧力が瞬間的に増加するため であると考えられる．また，横穴以外の領域においては，入 口からの距離が長くなるに伴い，管内圧力は減少しているこ とがわかる。これは，通常の配管と同様に管摩擦損失による 圧力損失が生じるためであると考えられる.

次に, 各横穴からの流出流量比を図 3 に示す. 縦軸および 横軸はそれぞれ, 入口流量 $Q$ に対する各横穴の流出流量 $q_{\text {out }}$ の比および入口からの距離である。〉，○および $\triangle$ お人口流 速 $V_{\text {in }}=0.5[\mathrm{~m} / \mathrm{s}], 1.5[\mathrm{~m} / \mathrm{s}]$ および $2.5[\mathrm{~m} / \mathrm{s}]$ の結果を示す.下 流側横穴 Outlet-2 の流出流量比は，いずれの入口流速におい ても上流側横穴 Outlet-1 に比べ高いことがわかる.また，各 横穴の流出流量比は，入口流速 $V_{i n}$ に関係なく同程度である ことがわかる．才なわち，入口流速 $V_{i n}$ の大きさが流出流量 比に及ぼす影響は小さいことがいえる.

流出流量を決定するパラメータを明らかにするため, 各横 穴から流出する水の流路面積に対する平均速度を図4に示す. 縦軸および横軸は, 入口流速 $V_{\text {in }}$ に対する平均流出速度 $V_{\text {out }}$ の流速比および入口からの距離を示す. 平均流出速度はいず れの横穴においても同程度であることがわかる，さらに，入 口流速に関係なく各横穴の流速比は同程度であることがわ かる.

図 5 に入口流速 $V_{i n}=0.5[\mathrm{~m} / \mathrm{s}]$ における各横穴出口断面で の水の流速分布を示寸. 流速分布中の白色の領域は空気であ る.いずれの横穴においても, 円形全てから流出しておらず, 三日月状の流路を形成していることがわかる。これは，横穴 に流入する際に主管内の主流速度が大きく, 流入する横穴内 を水で満たすことができないためである。この三日月状の流 路面積を有効流路面積と定義した. さらに, Outlet-2 の有効 流路面積は, Outlet-1 に比べ大きいことがわかる.これは, 上流側の横穴から水が流出したことにより，後方の管内の 主流速度が減少し, 後方の横穴ではより横穴に流入しやすく なったためであると考える.すなわち，前述のように各横穴 からの平均流出速度が同程度であるため, 連続の式より流出 流量を決定するパラメータは, 有効流路面積であることがい える。

\section{4. 結言}

横穴を 2 個設けた配管の管内圧力は, 横穴で大気に開放さ れ主管と横穴に分岐する際に急激に減少した後増加し, 管全 体では階段状に増加する。また，横穴では全面で流れるので はなく, 三日月状の流路を形成し, 有効流路面積が存在する. さらに, 下流側横穴の有効流路面積は上流側横穴に比べて大 きい. 寸なわち, 横穴からの平均流出速度が同程度であるこ とから, 流出流量を決定するパラメータは有効流路面積であ ることを明らかにした。

\section{参考文献}

（1）福原, 辻, 林, 空気調和・衛生工学会 1979 年 No.11, pp $37-43$

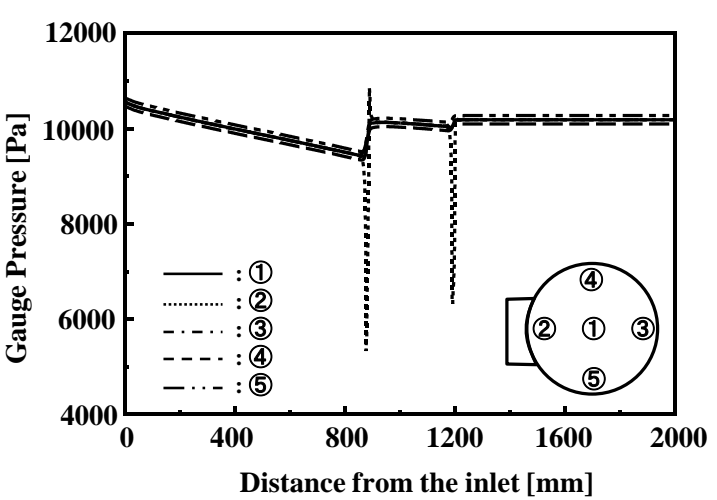

Fig.2 Pressure distribution along the pipe with two side-holes in case of $V_{\text {in }}=1.5[\mathrm{~m} / \mathrm{s}]$

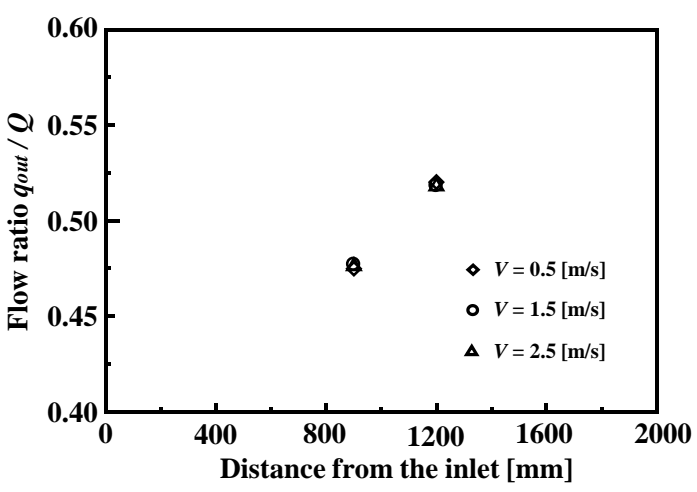

Fig.3 Discharge from side-holes

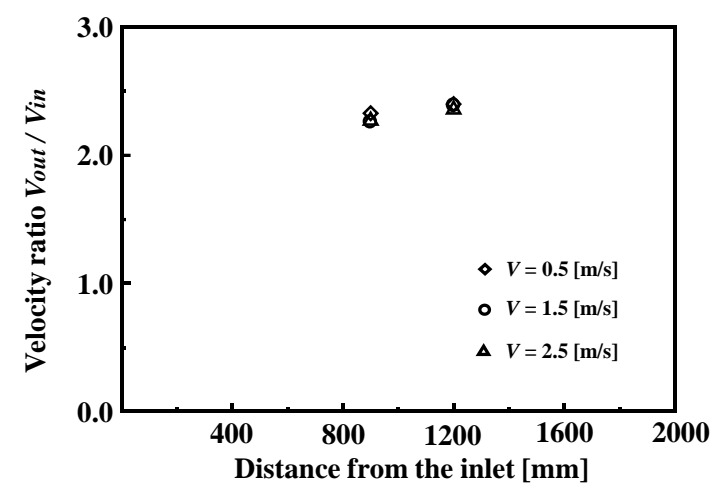

Fig.4 Mean velocity at the outlet of side-holes

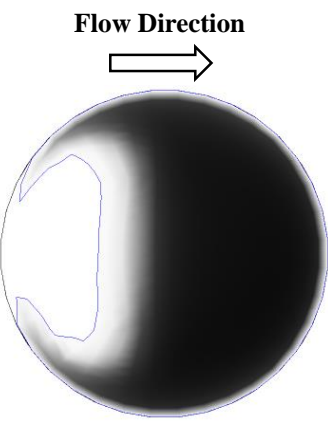

(a) Outlet - 1

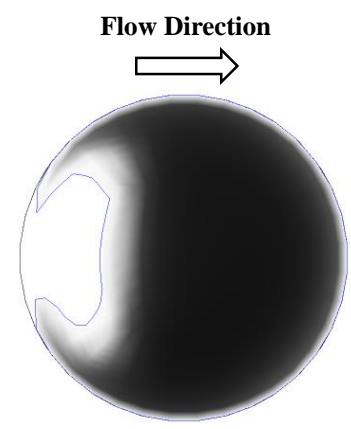

(b) Outlet - 2

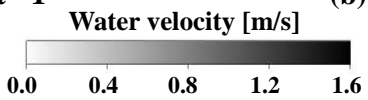

Fig.5 Velocity distributions at side-holes in $V_{\text {in }}=0.5[\mathrm{~m} / \mathrm{s}]$

（2）福原, 辻, 林, 空気調和 - 衛生工学会 1983 年 No.22, pp $71-78$ 